
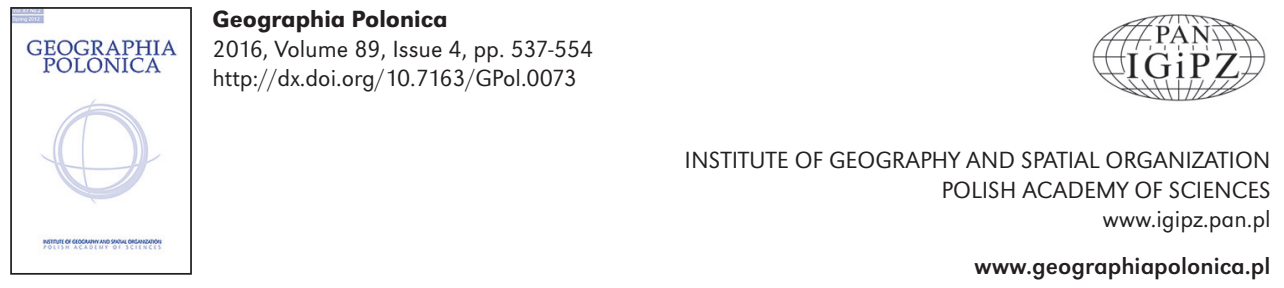

\title{
INTERMEDIATE SOCIAL HOUSING IN THE PARIS METROPOLITAN AREA
}

\author{
Magdalena Górczyńska \\ Institute of Geography and Spatial Organization \\ Polish Academy of Sciences \\ Twarda 51/55, 00-818 Warsaw: Poland \\ e-mail: mgor@twarda.pan.pl
}

\begin{abstract}
Intermediate social housing in France constitutes a segment of housing with regulated rents with income eligibility limits that are higher than in standard social housing, giving access to wider group of households. It is at aiding middle income households retain accessibility to housing, especially in cases of tight real estate markets, or to infuse a social mix. Using the database on social housing in 2014 and the population census of 2011, this article explores the distribution of intermediate social housing at departmental and communal levels in the Paris metropolitan area and the range of landlords who manage this stock. Secondly, it investigates more indepthly the role of intermediate social housing in the communes which are perceived to be socially differentiated. Finally, this paper provides different explanations for the phenomenon of rent reduction in intermediate social housing.
\end{abstract}

\section{Key words}

intermediate social housing $\bullet$ housing policy $\bullet$ middle-income households $•$ Paris metropolitan area

\section{Introduction}

This study, embedded in the classical discourse on the right to the city (Lefebvre 1968), addresses the question of the role of social housing differentiation in order to accommodate various groups of less fortunate households. The diversification of social housing articulated by housing and urban renewal policies is also seen to contribute to a greater social mix. According to the legal framework in France, a social mix shall be achieved through attainment by 2020 of a specific quota of social housing in communes, set up at $20 \%$ in 2000 by the SRU law (Fr. Solidarité et renouvellement urbain) and raised to 25\% in 2013, as well as through segmentation of social housing and differentiation of rents.

Several studies have shed light on the impact of various aspects of social mix policies (Lelévrier 2006; Préteceille 2012; Laine Daniel et al. 2013) and specifically of residential mobility of relocated people in the framework of social mix programs (Lelévrier 2008a, 2010; 
Lelévrier et al. 2007; Bacqué et al. 2010; Bacqué \& Fijalkow 2012) as well as on the role that public and institutional actors play in the distribution of social housing (Pinçon 1976; Lelévrier 2008b; Houard 2009). The majority of this research has focused on less affluent population and the diversification of the housing due to renovation or urban renewal projects implemented in the sensitive urban areas and in disadvantaged neighborhoods.

This paper focuses on intermediate housing as a segment of housing with regulated rents initially dedicated to middle-income households. It strives to address three research questions: what is the distribution of intermediate social housing? What social landlords manage this stock? What is contemporary role of intermediate social housing in the metropolitan area of Paris? The aim of this paper is threefold. Firstly, it explores the location of intermediate social housing at departmental and communal levels and the range of landlords who manage this stock. Secondly, it investigates more deeply the role of intermediate social housing in the communes which are perceived to be socially differentiated. Bearing in mind the objectives of public policy in France, the social mix at communal level was operationalized as diversification of inhabitants in terms of their incomes, using the classification elaborated by C. François and his team (2011). Finally, this paper provides different explanations to the phenomenon of rent reduction in intermediate social housing.

The interest in studying such a topic in Îlede-France region lies in the particular situation of this region which continues to attract new residents, especially young people (students and those who are beginning or continuing their professional careers) as well as highly skilled managers. This results in reinforced competition in the real estate market. According to the report prepared by the Observatory of rents in Paris agglomeration in 2012 (OLAP 2012), the highest rents on the free market concerned Paris (average 20-24€/ $\mathrm{m}^{2}$ ) and Hauts-de-Seine department (average $16-20 € / \mathrm{m}^{2}$ ) whereas the lowest rents concerned Val-de-Marne (average 13-19€/ $\mathrm{m}^{2}$ ) and Seine-Saint-Denis (average 11-19€/ $\mathrm{m}^{2}$ ). Indeed, 77 communes in Île-de-France representing tight real estate market were classified by the Ministry of Housing, Equality for territories and Rural Policy as zone 'A bis' or ' $A$ ' (2014). This classification entitles an application in each zone for particular financial schemes of support to home ownership and to the rental sector. The difficulty in access to housing is also reflected in the number of requests for social housing which amounted to 117 thousand in Paris and between 52-57 thousand in Hauts-de-Seine, Val-de-Marne and Seine-Saint-Denis departments in 2010 (IAU, 2011). The demand is the highest in the communes inhabited by households with lower incomes and where the number of social housing is already significant (IAU 2011; Rapport sur..., 2012). Furthermore, spatial disparities are clearly manifested in the real estate market (Atlas des Franciliens 2013). First of all, housing value is based on the distance from Paris, and subsequently it is dependent on specific location i.e. in the traditionally affluent areas, or areas now gaining position because of their proximity to highways and main employment zones (Berger 2004). In this perspective, the provision of an affordable supply of housing to meet the needs of different social groups remains one of the contemporary challenges in the Île-de-France region.

This article begins with a brief overview of the role of housing differentiation and summarizes different factors that affect differentiation of tenants in social housing in different Western European countries. This part is followed by a brief characteristic of the differentiation of social housing in France, including a focus on intermediate social housing. Then the data sources and methods which were used are presented. The fourth part, dedicated to empirical investigations, is divided into three subsections related respectively to: the distribution of intermediate social housing, differentiation of social landlords and entities with the right for reservation, and to the analysis of intermediate social housing with reduced rents in socially mixed communes. The main findings are presented in the final part. 


\section{Role of housing stock diversification}

The manifold research has shed light on the relationship between housing structures and social composition. The construction of new housing was indicated as one of the factors of filtering process (Hoyt 1939) resulting in the devalorization of older building, or contributing to a social upgrading associated with the process of 'new-build' gentrification (Davidson \& Lees 2005). In this perspective, the diversification of the housing stock relating directly to urban renewal policies was aimed at combating urban problems such as a deteriorating quality of housing, poverty, unemployment, social segregation etc. (Kleinhans 2004). However, diversification of housing by size, forms, price and especially by tenure became one of the basic political tools to achieve socially mixed neighbourhoods (Musterd \& Andersson 2005; Kearns \& Mason 2007; Lupton \& Tunstall 2008; Bretherton \& Pleace 2010; Bergsten \& Holmqvist 2013; Boschman et al. 2013; Livingston et al. 2013). On the other hand, Murdie and Borgegard (1998) argued that housing segmentation by tenure entailed the concentration of social

Table 1. Diversification of social landlords and target group of tenants in selected Western European countries

\begin{tabular}{|c|c|c|}
\hline & Providers of social housing & Social characteristics of tenants \\
\hline Austria & $\begin{array}{l}\text { Limited-profit housing associations (private } \\
\text { sector) }\end{array}$ & $\begin{array}{l}\text { Working class, disadvantaged people and } \\
\text { growing share of people with immigrant } \\
\text { background } \\
\text { Middle class }\end{array}$ \\
\hline $\begin{array}{l}\text { Belgium } \\
\text { (Flanders) }\end{array}$ & Mainly private organizations (State subsidies) & $\begin{array}{l}\text { Mainly for lower-income households who pay } \\
\text { income-dependent rents }\end{array}$ \\
\hline Denmark & $\begin{array}{l}\text { Municipal housing } \\
\text { Housing associations }\end{array}$ & $\begin{array}{l}\text { only } 2 \% \text { of social housing } \\
\text { marginalized groups and those with special } \\
\text { needs; increasing share of ethnic minorities }\end{array}$ \\
\hline Germany & $\begin{array}{l}\text { Public housing companies and housing } \\
\text { cooperatives } \\
\text { Private owners and private institutional } \\
\text { landlords }\end{array}$ & $\begin{array}{l}\text { Possible choice from eligible applicants but: } \\
\text { - in high-demand areas, landlords preferred } \\
\text { tenants with secure incomes; } \\
\text { - landlords having placement contracts with } \\
\text { municipalities could not reject 'problem' } \\
\text { tenants. }\end{array}$ \\
\hline Netherlands & $\begin{array}{l}\text { Private housing associations with public task } \\
\text { (overtaken municipal counterparts by the } \\
\text { mid 1970s) }\end{array}$ & $\begin{array}{l}\text { Socially mixed tenants due to: } \\
\text { - large share of social housing ( } 31 \% \text { within } \\
\text { the total housing stock) } \\
\text { - regulated but differentiated rents (cheaper } \\
\text { flats, mid-priced and more expensive). }\end{array}$ \\
\hline UK & $\begin{array}{l}\text { Housing Associations non-profit independent } \\
\text { landlords (currently manage } 54 \% \text { of social } \\
\text { housing) and local authorities }\end{array}$ & $\begin{array}{l}\text { Mainly for lower income households but differ- } \\
\text { ent segments of housing exist: } \\
\text { - socially rented (even lower than } 50 \% \text { of lo- } \\
\text { cal market rent), } \\
\text { - affordable rented (up to } 80 \% \text { of local } \\
\text { market rent), } \\
\text { - intermediate housing (can be aimed at 'key } \\
\text { workers' defined by the government). }\end{array}$ \\
\hline
\end{tabular}

Source: based on: Murie and Musterd (1996); Whitehead and Scanlon (2007); Winters and Elsinga (2008). 
groups in particular tenure types. Mixing tenures was therefore perceived as a tool to tackle the problems of social exclusion, particularly in disadvantaged neighbourhoods (Graham et al. 2009). Graham and others (2009) underscored that the beneficial effects of social mix through tenure differentiation were only obtained at particular thresholds of public housing in neighbourhoods. Hence, the discussion on an appropriate threshold of social housing has begun (Abraci \& Rae 2013).

Not only tenure mixing but also the legal framework and differentiation within social housing were seen as a tool for social diversification in neighbourhoods. The examples from European countries show that three factors may differentiate features of social tenants: level of restrictions on access to social housing, differentiation of segments of social housing (rents level) as well as quality and localization of social housing. For instance, in Denmark, Sweden or the United Kingdom, there are no income limits for entry to social housing and the sector is theoretically open for a wider population. In Austria, despite the fact that the income limits are fixed, they are rather high, while in Ireland or Belgium, the income limits are much stricter (Whitehead \& Scanlon 2007; Winters \& Elsinga 2008). This legal framework for social housing provision impacts the number of residents eligible for social housing in each country.

Secondly, the diversity of social housing providers also affects social features of tenants (Tab. 1). Public institutions are more often in charge of housing for the disadvantaged population whereas private landlords or nonprofit associations more frequently offer social flats for middle-income households. Nevertheless, such specializations are strongly dependant on national legal frameworks concerning social housing and priority goals.

Finally, the quality of social housing determined by the period of construction may result in different socio-demographic features of tenants, such as in Austria: young families live in newer municipal housing while older population in older estates (Whitehead \& Scanlon 2007). In Germany, only good quality and localization in 'good' neighbourhoods create a positive image of social housing which as a consequence may attract higher-income households (Whitehead \& Scanlon 2007).

\section{Differentiation of social housing in France}

In France, public intervention in the provision of social housing began in 1912 when the law Bonnevay imposed on the public sector an obligation to support housing for blue-collar workers. A few years later, the housing crisis in the inter-war period affected all social groups and housing offices (Fr. Habitation à Bon Marché, HBM) began to differentiate their offers. The construction of bigger and better-equipped flats with higher rents (Fr. immeubles à loyer moyen, ILM) was dedicated to middle-income households stemming from the new middleclass: lower-grade civil servants and employees in the tertiary sector (Stébé 2009). In this way, three main categories of social housing were developed: dwellings for the modest population, ordinary social flats and intermediate ${ }^{1}$ (Genest 2005).

Over the years, the role of social housing has significantly evolved. In the 1950s and 1960s, living in large housing estates with regulated rents (Fr. Habitation à loyer modéré, HLM) equipped with "all installations" represented social promotion (Stébé 2009). Till the 1970s, the HLM were mostly occupied by young households of blue-collar and whitecollar workers, who were beginning their residential trajectory and upward social mobility (Horenfeld 1998). Since then, there has been a profound change in the profile of social housing tenants with an increase in the number of elderly population due to "ageing in place" and residualisation process (Horenfeld 1998).

Apart from the diversification of social housing types aimed at the accommodation of a wider range of social groups, the social

\footnotetext{
1 For instance: buildings with average rents ILM (Fr. immeubles à loyer moyen) introduced by the law Loucher in 1928; buildings with normal rents ILN (Fr. immeubles à loyer normal) introduced in 1957.
} 
profiles of tenants also varied with respect to different sorts of landlords (Fr. bailleurs) in charge of them. Each category of landlord presented specific strategies and specialization in terms of dwellings' attribution to particular types of households (Pinçon 1976). For instance, local, departmental or other public agencies (Fr. offices publics de l'habitat, $\mathrm{OPH}$ ) set up by local authorities are in charge of flats for the lowest-income households. Social enterprises for housing (Fr. entreprise sociale d'habitat, ESH) are private bodies but the representatives of local authorities are among the members of directors' council. Households with higher incomes are better represented among their tenants. Societies with a predominating public capital (Fr. sociétés d'economie mixtes, SEM) have at least one private shareholder and are managed usually by the local mayor or his representative. In this way, the social composition in flats administrated by these institutions may correspond to a particular vision supported by the local mayor and his party. Finally, housing cooperatives (Fr. sociétés coopératives) accommodate mainly managerial staff (Pinçon 1976), however the share of flats that they manage is very low, so their role as social landlords is marginal. Recent studies have shown that the profiles of social tenants were strongly linked to the decisions of social landlords and local mayors who created "local attribution rule" with regard to social housing (Bourgeois 2004; Houard 2009).

This picture becomes more complex if we add another group of actors affecting allocation of social flats: reserving entities. This group includes: public institutions controlled by the state (flats for civil servants, priority households), local communities and local public institutions (flats for different types of households), employers and fund collecting bodies "1\%-Logement" (flats for employees)

\footnotetext{
2 Private entrepreneurs (employing more than 20 employees) grouped in the framework of a jointstock company - Union of Entrepreneurs and Employees for Housing (Fr. Union des Entreprises et des Salariés pour le Logement, UESL). Since 1953, the UESL has been collecting funds to support social housing under
}

and others. The listed entities obtain the right to reserve a certain share of newly developed flats in return for their financial support or material contribution (e.g. building plot) offered to landlords. In this way, they may put 'their' tenants in a flat allocation procedure.

Nowadays, the segmentation of social housing relates to the diversification of rent and income ceilings according to the type of direct or indirect support attributed to social and private landlords for the construction, acquisition or rehabilitation of housing. At the turn of the 20th and 21st centuries, regarding the law on housing and construction (Fr. code de la construction et de l'habitat) four main types of contemporary loans aimed at supporting the construction or rehabilitation of rented housing with regulated rents were fixed (PLA I, PLUS, PLS, PLI and associated loans ${ }^{3}$ ). The income limits for different types of households and rent ceilings are determined yearly (Tab. 2). Indeed, four types of loans correspond to different types of rental housing: very social housing for low-income households (PLA I and associated), standard social housing (PLUS and associated), intermediate social housing (PLS and associated) and intermediate housing (PLI and associated). Should the incomes of tenants in social housing increase over the years, or their personal situation changes and as a result they exceed the ceilings established in a particular type of social housing, they may still remain as tenants but have to pay an increased rent ${ }^{4}$.

In general, intermediate housing PLS and PLI have two main functions: to remain accessible to the middle-income households, especially in the case of tight real estate markets, or to infuse a social mix (Joinet 2011b). Nevertheless, the significance of intermediate housing was often criticized in Île-de-France region.

the name "Operation Flat" (Fr. Action Logement). Affiliated entrepreneurs pay $1 \%$ of the amount of paid salaries.

3 PLA I - Prêt Locatif Aidé d'Insertion; PLUS - Prêt Locatif à Usage Social; PLS - Prêt Locatif Social; PLI Prêt Locatif Intermédiaire.

${ }^{4}$ An increased rent is applied when the income exceeds the fixed limits at $20 \%$. 
Table 2. Annual income limits for households seeking dwellings with regulated rent in Paris and surrounding communes (as of 9 January 2015), as well as levels of rent (as of 18 March 2014)

\begin{tabular}{|l|c|c|c|c|}
\hline \multirow{2}{*}{ Household types } & \multicolumn{4}{|c|}{ Income limits in different types of dwellings (euro) } \\
\cline { 2 - 5 } & PLAI & PLUS & PLS & PLI \\
\hline 1-person households & 12,722 & 23,127 & 30,065 & 41,629 \\
2-persons households except young households & 20,740 & 34,565 & 44,935 & 62,217 \\
3-persons households, or 1 person + dependent & 27,186 & 45,311 & 58,904 & 74,790 \\
person, young households & 29,757 & 54,098 & 70,327 & 89,584 \\
4-person households, or 1 person + 2 dependent & & & & \\
persons & 35,399 & 64,365 & 83,675 & 106,051 \\
5-person households, or 1 person + 3 dependent & & & & 119,340 \\
persons & 39,836 & 72,429 & 94,158 & \\
6-person households, or 1 person + 4 dependent & & & & $>13,298$ \\
persons & $>4,438$ & $>8,070$ & $>10,491$ & 18.38 \\
Additional person in household & 5.94 & 6.66 & 13.00 & \\
Maximum rent level (per sq. $m$ ) & & &
\end{tabular}

* sum of age of all the members of a household does not exceed 55 years

Source: http://vosdroits.service-public.fr/particuliers/F869.xhtml

Firstly, it was questioned whether the segment which constituted between 9 and $13 \%$ in 2009 (Joinet 2011b), was capable of addressing the housing needs of quite a large group of middle-income households in the Île-de-France (see Préteceille 2012). Secondly, criticism regarding low relevance stemmed from an estimation that only $9 \%$ of households (tenants in privately owned or social dwellings) in the île-de-France region could potentially become tenants as their incomes corresponded to the PLS or PLI ceilings (Guillouet 2011). Thirdly, although rent and income ceilings are fixed, the minimum level of rents and incomes in each segment of social housing are not determined. Thus, the social landlords may reduce rents in intermediate housing to accommodate lower-income households in the dwellings which were a priori destined for middle-income tenants, thus undermining the initial role of this housing stock. Finally, criticisms concerning intermediate housing were also based on the findings that households with incomes corresponding to PLS and PLI levels usually head towards home ownership (Joinet 2011b). Nevertheless, the first basic analyses of rent differential between the PLS rent and market rents have shown that the PLS housing are still competitive with those in home ownership, particularly in Paris, in the inner suburbs (except northern part) and in the southwest part of external suburbs (Brimbal 2011).

\section{Study area, database and methods}

The study area defined in this paper as the metropolitan area of Paris covers four departments (124 communes): Paris, Hauts-deSeine, Seine-Saint-Denis and Val-de-Marne (Annex 1). This area is highly diversified in terms of housing and social structures. Several studies on the social division in the île-de-France region showed that the most affluent territories extended from the western districts of Paris towards the west and southwest in Hauts-de-Seine department, while the 
majority of communes in Seine-Saint-Denis department displayed the highest poverty rates (Pinçon \& Pinçon-Charlot 2004; Préteceille 2003, 2006, 2012; Sagot 2013). This social division observed in the central part of the metropolitan area also extends to the periurban space (Rhein \& Berger 1988; Berger \& Saint-Gérand 1993), where the large share of more affluent population in the southwest sector is explained by the proximity of the valorized residential suburbs and employment areas for high-skilled employees (Berger 2004). Moreover, this socio-economic polarization also relates to sensitive urban areas (Fr. zones urbaines sensible, ZUS) in the Île-de-France region, where they are struggling with socioeconomic problems. According to the typology proposed by F. Jacquesson (2006: 2-6), most of ZUS in Seine-Saint-Denis were classified as "very poor, facing poverty and difficulties in terms of employment opportunities", whereas the majority of ZUS in Hauts-de-Seine were described as "intermediate, whose profile corresponded to ZUS's average in the region but with a lower percentage of foreign population from outside the European Union".

The quantitative analyses are based on secondary data sources issued from: the social housing stock directory (Fr. répertoire du parc locatif social RPLS, 2014) and population census (Fr. recensement de la population RP, 2011). The RPLS contains information on social housing managed by social landlords including: different types of loans used to finance housing, construction periods, dates when each flat entered social housing stock, as well as the average rent per square meter.

This paper focuses on intermediate social housing financed by PLS loans (and associated) because according to the SRU law, dwellings financed by PLI loans are not counted as social housing (although their rents are regulated). With relation to the typology applied by the Observatory for social housing, I assembled under the name "intermediate social housing" the flats financed by PLS loans and associated which operated in different periods: PACP, PLACFF, PCLS, PAP and PCL. As a result, the group of analyzed intermediate social housing includes the flats built in various periods, which makes this group heterogeneous (Tab. 3).

Descriptive statistics and the calculation of Spearman correlation coefficients enabled to explore the role of intermediate social housing and to identify whether any statistical interdependencies existed between the phenomena investigated.

Table 3. Construction periods of intermediate social housing by department

\begin{tabular}{|l|c|c|c|c|c|c|c|c|}
\hline \multirow{2}{*}{$\begin{array}{c}\text { Construction } \\
\text { periods }\end{array}$} & \multicolumn{2}{|c|}{ Paris } & \multicolumn{2}{c|}{ Hauts-de-Seine } & \multicolumn{2}{c|}{ Seine-Saint-Denis } & \multicolumn{2}{c|}{ Val-de-Marne } \\
\cline { 2 - 9 } & $\begin{array}{c}\text { Absolute } \\
\text { values }\end{array}$ & $\%$ & $\begin{array}{c}\text { Absolute } \\
\text { values }\end{array}$ & $\%$ & $\begin{array}{c}\text { Absolute } \\
\text { values }\end{array}$ & $\%$ & $\begin{array}{c}\text { Absolute } \\
\text { values }\end{array}$ & $\%$ \\
\hline before 1949 & 1,458 & 8.2 & 1,359 & 7.5 & 373 & 3.1 & 243 & 1.8 \\
$1949-1974$ & 4,256 & 23.9 & 6,748 & 37.0 & 4,184 & 35.1 & 7,314 & 53.7 \\
$1975-1981$ & 1,385 & 7.8 & 653 & 3.6 & 645 & 5.4 & 288 & 2.1 \\
$1982-1989$ & 4,389 & 24.7 & 1,944 & 10.7 & 717 & 6.0 & 988 & 7.3 \\
$1990-1998$ & 1,809 & 10.2 & 1,554 & 8.5 & 563 & 4.7 & 1,224 & 9.0 \\
$1999-2008$ & 3,041 & 17.1 & 2,468 & 13.5 & 1,852 & 15.5 & 2,285 & 16.8 \\
$2009-2013$ & 1,451 & 8.2 & 3,491 & 19.2 & 3,597 & 30.1 & 1,278 & 9.4 \\
Total & 17,789 & 100 & 18,217 & 100 & 11,931 & 100 & 13,620 & 100 \\
\hline
\end{tabular}

Source: RPLS, 2014. 


\section{Intermediate social housing in the metropolitan area of Paris}

The following sections are dedicated to the analysis of the distribution of intermediate social housing, the role of this segment with regard to types of social landlords that manage this stock and to types of entities which reserved them. Finally, it explores the phenomenon of rent reduction in intermediate social housing with attention paid to mixed communes (in terms of inhabitants' incomes). The overview of scientific literature on housing diversification and on intermediate social housing enabled me to formulate three hypotheses.

(1) With respect to French housing policy goals and to two roles attributed to intermediate social housing, this segment of social housing shall be positively correlated with the percentage of social housing in the communes.

(2) Considering the initial role of intermediate housing (to accommodate middle-income households) and specialization of different sorts of landlords in the accommodation of particular types of tenants, private social landlords (social enterprises, ESH) shall manage a greater number of this segment of social housing than other types of landlords. Moreover, reserving entity "1\% Logement" will reserve more intermediate social housing than other reserving entities.

(3) Because of the tight housing market in the Paris metropolitan area and growing demands for social housing, in the communes with more than $25 \%$ of social housing, intermediate social housing becomes standard social housing and accommodates lower-income households.

\section{Spatial pattern of intermediate social housing in the metropolitan area of Paris}

Since its creation in 2001, the number of intermediate social housing among newly constructed social housing continues to grow. In total, this segment constitutes around 17\% of the dwellings that have entered the

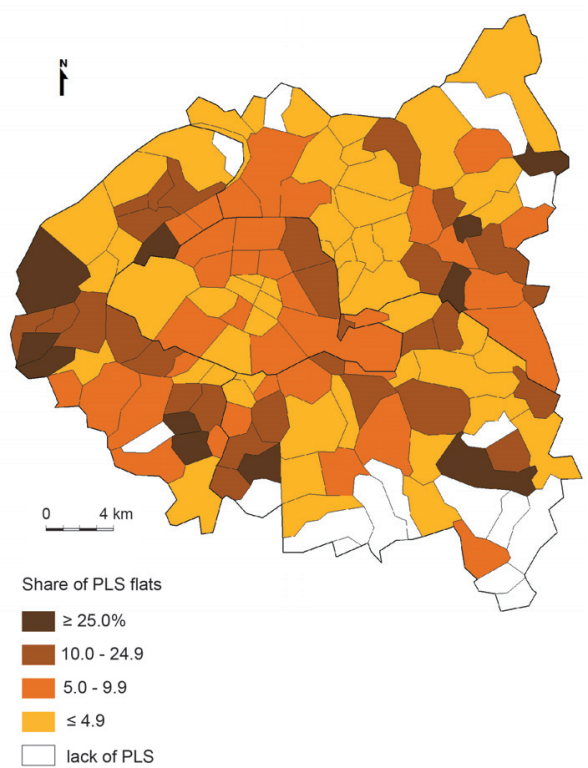

Figure 1. Share of intermediate social housing in the stock of social landlords in 2014

Source: on the basis of RPLS, 2014.

social housing stock since 2001 in Paris, 33\% in Hauts-de-Seine, $23 \%$ in Seine-Saint-Denis and $28 \%$ in Val-de-Marne. In 2014, intermediate social housing constituted more than a quarter of social dwellings in eleven communes in the Île-de-France region (Fig. 1).

The position of intermediate social housing as one of the segments of social housing was assessed using Spearman ${ }^{5}$ correlation coefficient. The value of the coefficient $(p<0.05)$ equal to -0.2530 , provides two important pieces of information. Firstly, the share of intermediate housing is higher in municipalities with a lower share of social housing on their territory. This result indicates that at this scale, the probability that intermediate social housing acts as a tool for achieving the required number of social housing is greater. This result also contradicts the thesis that the intermediate social housing is aimed at reinforcing the diversification of the housing stock in municipalities

\footnotetext{
5 Rang correlation coefficient is better adapted to measure the relations between the variables which do not have a normal distribution.
} 
with a significant percentage of social housing. However, the value of the correlation coefficient is relatively low and does not allow us to confirm straightforwardly the first hypothesis. Interestingly, at the departmental level, the types of relations between the two variables take different directions (Fig. 2, Tab. 4).

In the light of these findings, we argue that in Paris attempts were made to create a social mix rather by the strategy corresponding to the construction of intermediate social housing in the districts that already had a high share of social housing. Nevertheless, in two neighboring departments (Hauts-de-Seine and Seine-Saint-Denis) the relationship between the variables was opposite: negative values of correlation coefficients indicated that more PLS housing were present in the areas with a lower share of social housing. This common finding was somehow striking considering the fact that the communes in Hauts-de-Seine and Seine-Saint-Denis are specialized in attracting different social groups and they therefore
Table 4. Spearman correlation coefficients between the share of PLS housing and the share of social housing

\begin{tabular}{|l|c|}
\hline \multicolumn{1}{|c|}{ Department } & $\begin{array}{c}\text { Correlation } \\
\text { coefficient }\end{array}$ \\
\hline $\begin{array}{l}\text { Paris } \\
\text { (calculated for } 20 \text { districts) }\end{array}$ & 0.5789 \\
$\begin{array}{l}\text { Hauts-de-Seine (92) } \\
\text { (calculated for } 36 \text { communes) }\end{array}$ & -0.5665 \\
$\begin{array}{l}\text { Seine-Saint-Denis (93) } \\
\text { (calculated for 40 communes) } \\
\text { Val-de-Marne }(94) \\
\text { (calculated for 47 communes) }\end{array}$ & -0.5044 \\
\hline
\end{tabular}

$\mathrm{p}<0,05$ except Val-de-Marne

Source: on the basis of RPLS, 2014; RP, 2011.

represent completely divergent socio-economic profiles (even though they have a certain level of internal social differentiation). This analysis provided a general picture of the relationship between the share of a particular

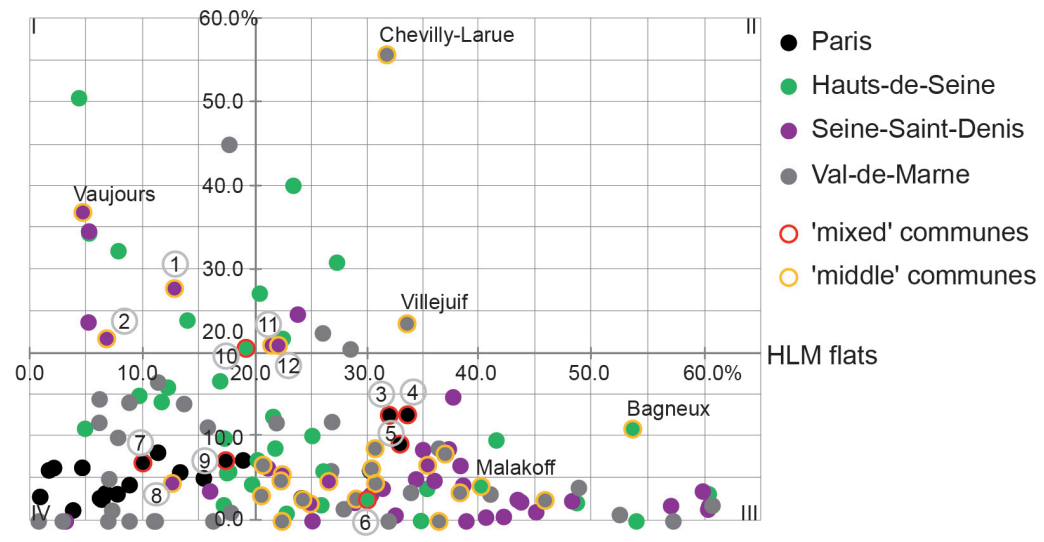

PLS flats
(1) Neuilly-Plaisance
(7) 10 e arrondissement
(2) Les Pavillons-Sous-Bois
(8) Livry-Gargan
(3) $19 e$ arrondissement
(9) $18 \mathrm{e}$ arrondissement
(4) 20 e arrondissement
(10 Asnières-sur-Seine
(5) $13 e$ arrondissement
(11) Gagny
(6) Colombes
12 Rosny-sous-Bois

Figure 2. The share of PLS housing (in the social housing) and the share of social housing in communes (by departments)

Source: on the basis of RPLS, 2014; RP, 2011. 
segment of a social housing and a social housing as a whole, but it tends to overshadow the complexity of situations at the communal level. This problem has particularly affected the areas classified as intermediate or mixed in terms of household incomes (cf. François et al. 2011). These communes apply different strategies in relation to intermediate social housing (Fig. 3). Considering the share of social housing and PLS housing in each commune, we could distinguish four types of situations.

In the first group, intermediate social housing is an instrument for achieving the share of housing required by law. The fact that certain 'intermediate' communes have a small share of social housing and a substantial share of the PLS housing can be interpreted as a strategy to "avoid impoverishment" by having an increase in the amount of social housing. Such examples (i.e. Vaujours,

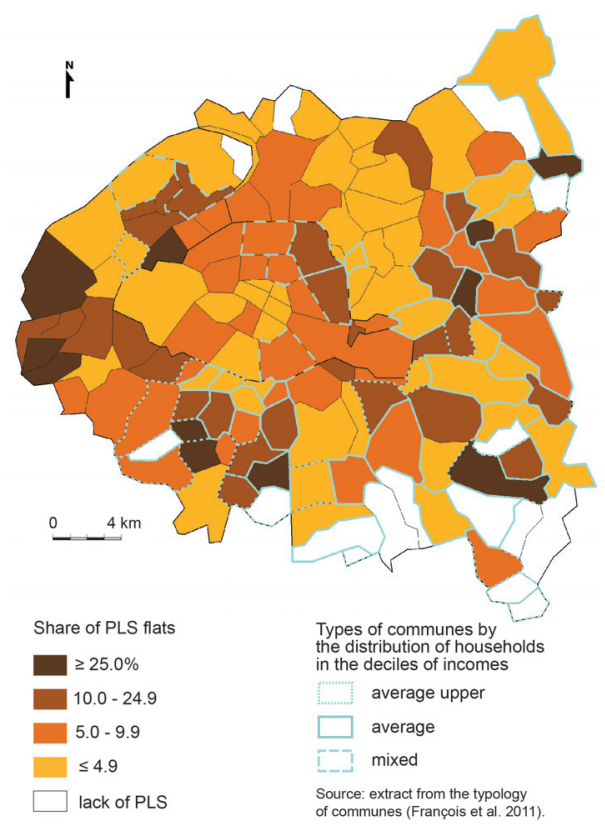

Figure 3. The distribution of intermediate social housing and 'intermediate' communes in the metropolitan area of Paris

Sources: on the basis of RPLS, 2014; François et al. (2011).
Pavillons-sous-Bois, Neuilly-Plaisance) could be found particularly in the eastern part of Seine-Saint-Denis department where the average prices on the housing market are already relatively low contrary to the three other departments. Thus, the construction of standard social housing could potentially have threatened the social profile of the intermediate communes located in this area.

The second group where the large share of PLS housing is followed by a significant number of social flats in general is the smallest. It gathers intermediate communes and those inhabited by more affluent residents (e.g. Sceaux, Rueil-Malmaison). Intermediate social housing represents an alternative for the middle-class, introduced in these areas especially in recent years as the majority of intermediate social housing entered the housing stock after 2009.

The third group comprises a wide range of situations. In certain communes, contemporary segmentation of social housing tends to be a less important tool in creating or retaining an 'intermediate' profile of their population since the latter refers to the long history of settlement, favoring certain social categories. In these communes, the share of social housing corresponds or almost reaches the required quota (between 20-25\%), while the share of PLS social housing is low. Such examples could be found mainly in Val-de-Marne and Hauts-de-Seine departments where the prices in the housing market are sky-high or at least high (Atlas des Franciliens 2013). On the other hand, numerous poor communes (mainly from Seine-Saint-Denis department) appear in this group, which means that they don't use intermediate social housing as a tool to differentiate social housing stock and by this means the social composition of tenants.

Finally, the most numerous fourth group includes communes with a low share of social and intermediate social housing, mainly in Val-de-Marne and districts in Paris. The large number of them represents upper-intermediate or affluence in terms of residents' incomes. 


\section{Types of landlords and types of reserving entities}

In this subsection, we will attempt to provide knowledge on the types of landlords managing intermediate social housing and reserving entities of this housing segment in the Paris metropolitan area. Apart from Paris, the share of social housing administrated by private landlords (ESH) reaches more than $40 \%$ in the three surrounding departments (Tab. 5, Fig. 4). These values even increase with respect to intermediate social housing. There were however around 30 different private entities who managed this stock in each department, with one bigger landlord - SA HLM Immobilière 3F which administrated around 20\% of all intermediate social housing. Only in Seine-Saint-Denis department did private landlords become particularly specialized in the management of intermediate social housing (the majority of this stock was in their hands). On the one hand, the greater diversification of landlords in other departments gives an opportunity to lessen specialization and to diversify the social housing stock of each landlord. On the other hand, a consistent management of social housing in a given territory becomes more difficult if their property is divided among various entities operating in line with different goals.
Concerning the different sorts of reserving entities, in 2014 intermediate social housing was not particularly reserved by associations of employers as it was supposed. In Paris, almost $40 \%$ of them were reserved by local

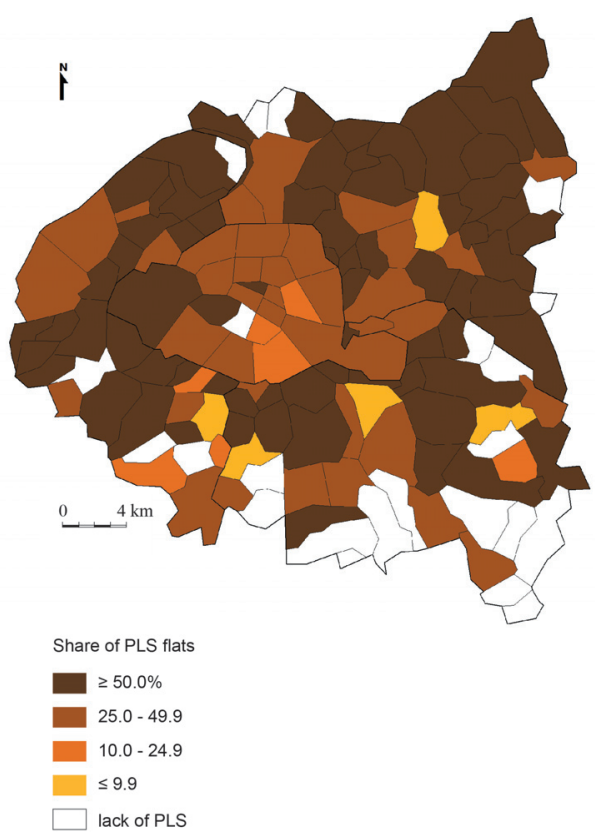

Figure 4. Distribution of intermediate social housing of private landlords (ESH) by communes Sources: on the basis of RPLS, 2014.

Table 5. Share of social housing by types of landlords in departments in 2014

\begin{tabular}{|l|r|r|r|r|r|r|r|r|}
\hline \multirow{2}{*}{} & \multicolumn{2}{|c|}{ Paris } & \multicolumn{2}{c|}{ Hauts-de-Seine } & \multicolumn{2}{c|}{ Seine-Saint-Denis } & \multicolumn{2}{c|}{ Val-de-Marne } \\
\cline { 2 - 9 } & All & PLS & All & PLS & All & PLS & All & PLS \\
\hline OPH-municipal & 52.8 & 19.1 & 34.6 & 5.9 & 27.7 & 9.6 & 27.6 & 7.5 \\
OPH-departmental & 0.1 & 0.5 & 16.6 & 22.0 & 12.5 & 0.5 & 3.3 & 0.9 \\
OPH-other & - & - & 3.7 & 2.6 & 8.3 & 6.2 & 19.4 & 32.1 \\
ESH & 24.8 & 32.7 & 41.1 & 57.9 & 47.6 & 70.2 & 43.3 & 47.2 \\
Cooperatives & 0.3 & - & - & 0.3 & 0.2 & - & - & 0.3 \\
SEM & 21.6 & 46.5 & 2.9 & 5.9 & 2.7 & 1.5 & 5.4 & 2.3 \\
Others & 0.4 & 1.3 & 0.7 & 5.6 & 1.0 & 11.9 & 1.0 & 9.8 \\
Total & $100 \%$ & $100 \%$ & $100 \%$ & $100 \%$ & $100 \%$ & $100 \%$ & $100 \%$ & $100 \%$ \\
\hline
\end{tabular}

Source: based on RPLS, 2014. 
Table 6. Share of social housing by types of reserving entities by departments in 2014

\begin{tabular}{|c|c|c|c|c|c|c|c|c|}
\hline & \multicolumn{2}{|c|}{ Paris } & \multicolumn{2}{|c|}{ Hauts-de-Seine } & \multicolumn{2}{|c|}{$\begin{array}{l}\text { Seine-Saint- } \\
\text { Denis }\end{array}$} & \multicolumn{2}{|c|}{ Val-de-Marne } \\
\hline & All & PLS & All & PLS & All & PLS & All & PLS \\
\hline State public officials and agents & 3.6 & 4.0 & 5.3 & 3.9 & 4.8 & 2.2 & 5.2 & 3.5 \\
\hline $\begin{array}{l}\text { Priority State within the meaning } \\
\text { of Article L. } 441-1\end{array}$ & 18.7 & 17.5 & 14.3 & 14.0 & 10.8 & 10.9 & 15.7 & 15.7 \\
\hline $\begin{array}{l}\text { Employers and collecting bodies } \\
\text { of the " } 1 \% \text { Logement" }\end{array}$ & 11.4 & 18.6 & 14.9 & 17.1 & 13.3 & 13.2 & 14.9 & 22.9 \\
\hline $\begin{array}{l}\text { Local authorities, their public } \\
\text { institutions and } \mathrm{EPCl}^{\star}\end{array}$ & 32.5 & 38.3 & 17.4 & 17.9 & 15.2 & 10.8 & 17.3 & 16.6 \\
\hline $\begin{array}{l}\text { Reservation of the State for hous- } \\
\text { ing officials through conventions } \\
\text { laid down in Articles R. } 314-4 \text {, } \\
\text { R. } 314-16 \text { and R. } 314-21\end{array}$ & 3.0 & 2.5 & 1.2 & 1.2 & 0.7 & 0.8 & 2.8 & 1.4 \\
\hline Other reserving entities & 3.9 & 4.5 & 4.5 & 8.3 & 9.6 & 9.3 & 6.3 & 4.2 \\
\hline Unreserved & 26.7 & 14.4 & 41.9 & 36.9 & 43.3 & 50.2 & 37.7 & 34.4 \\
\hline No data & 0.3 & 0.0 & 0.5 & 0.7 & 2.2 & 2.6 & 0.2 & 1.4 \\
\hline Total & $100 \%$ & $100 \%$ & $100 \%$ & $100 \%$ & $100 \%$ & $100 \%$ & $100 \%$ & $100 \%$ \\
\hline
\end{tabular}

* EPCl, établissement public de coopération intercommunale - public establishment of intermunicipal cooperation

Source: RPLS, 2014.

authorities, while in the three other departments, intermediate social housing stayed unreserved, which contradicts formulated hypothesis. Especially in Seine-Saint-Denis, in the case of intermediate social housing, social landlords have a greater impact on the selection of tenants than reserving entities.

\section{Rents in the intermediate social housing}

Due to a tight housing market in the Île-deFrance region and a growing demand for social housing, the distribution of intermediate dwellings to the modest residents instead of middle-income households has been criticized by several scholars. However, the statistics concerning this issue were sketchy or restrained to quite narrow samples. Indeed, the problem seemed to be overestimated as in 2014, the reduced rents concerned only
$5.8 \%$ of intermediate social housing in Paris, $8.3 \%$ in Hauts-de-Seine, $12.4 \%$ in Seine-SaintDenis and $14.0 \%$ in Val-de-Marne (RPLS 2014). In total, only in eight communes did reduced rents occur in more than one quarter of the PLS housing (Fig. 5). Nevertheless, the phenomenon corresponds to a wide range of situations (see Figs. 1 and 3) and for this reason it cannot be directly explained through a quantitative analysis. Indeed, the reductions of rents in PLS housing appeared in different types of communes in terms of household incomes, though more commonly in communes with a greater share of social housing e.g. Bagneux (Hauts-de-Seine), Bondy, Neuilly-SurMarne, Sevran (Seine-Saint-Denis), Villejuif (Val-de-Marne). This confirms the attempts undertaken to adapt the social housing offer to strong local demand for standard social housing. On the other hand, the reduction of rents occurred in a couple of communes in the Val-de-Marne department with a lower 
share of social housing and classified as middle-upper in terms of residents' incomes e.g. Sucy-en-Brie, Noiseau. However, the reduction of rents in intermediate social housing rarely concerned communes where the prices in the real estate market are the highest (in Paris and in the southwest part of suburbs).

Moreover, in many intermediate social flats the rents were actually raised: in $10.4 \%$ of them in Paris, $28.8 \%$ in Hauts-de-Seine, $15.6 \%$ in Seine-Saint-Denis and $14.9 \%$ in Valde-Marne (RPLS 2014). This means that intermediate social housing still remains attractive for middle-income households who prefer to stay in a particular department or commune where prices on the private market are higher. For instance, in the communes classified as affluent (François et al. 2011) such as: Antony, La Garenne-Colombes, Sceaux

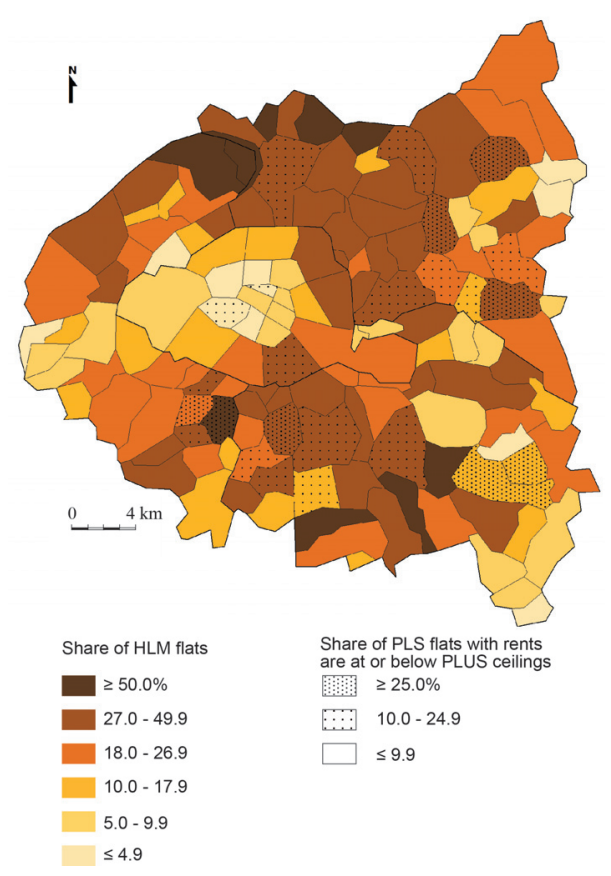

Figure 5. The share of social housing and the share of PLS housing with reduced rents In order to calculate the categories of rents the localization of communes in the Zone 1 bis and Zone 1 in 2014 was considered (before the revision introduced by the decree on the 1st August 2014). Source: on the basis of RPLS, 2014; RP, 2011.
(Hauts-de-Seine), Le Raincy (Seine-Saint-Denis), more than half of intermediate social flats had increased rents.

\section{Conclusions}

This study examined the position of intermediate social housing within the social housing stock in the Paris metropolitan area. Although their share is not yet sufficient to significantly influence the housing structures and in this way the social composition in communes, their number continues to grow and their significance could be reinforced in the future. In addition, the creation of the Grand Paris metropolitan area in 2016 shall undoubtedly affect housing as theoretically one common housing policy for the metropolitan area shall be set up. Hence, new relations between local actors may affect the role of intermediate social housing in the metropolitan territory.

This quantitative analysis revealed that the role of intermediate social housing is much nuanced and differs importantly between Paris and communes in different parts of the suburban area. Indeed, beyond the two primary objectives assigned to this segment (facilitate or create a social mix of properties for the middle class in a particularly tight real estate market), the construction of intermediate social housing enables the municipalities to reach the threshold of $20-25 \%$ of social housing on their territories. However, this strategy does not directly address the needs of the local people. These decisions probably reflect a willingness to maintain a particular socio-economic profile.

The first hypothesis could not be accepted for the whole of the Paris metropolitan area but was true in the case of Paris commune. In Hauts-de-Seine and Seine-Saint-Denis the relationships were divergent. In addition, the analyses of the relationship between social and intermediate social housing revealed different scenarios occurring in the communes appertaining to different groups in terms of residents' incomes. In the case of communes inhabited by middle or upper social groups but lacking the required number 
of social housing, the construction of intermediate social housing served as a strategy to "avoid impoverishment" as a possible result of an increase in the number of social housing. Surprisingly, in Seine-Saint-Denis characterized by a high concentration of social housing, the share of intermediate social housing was very low. Nevertheless, this does not mean that no local strategies exist to attract middle-income households. For instance, the analyses of local policies in Saint-Denis commune revealed that since the 1990s the local strategies have been revolving around increased construction of dwellings in 'social' home ownership ${ }^{6}$ or normal home ownership (Raad 2014). As a consequence, intermediate social renting was less frequently used as a tool for diversification of social composition.

Only the first part of the second hypothesis could be accepted for the three suburban departments as more than half of intermediate social housing was managed by private landlords. In Paris, this concerned only one third of intermediate social housing. However, private landlords appeared as important actors managing social housing stock in general, not only in this particular segment. The analysis of reserving entities revealed that the reserving entity " $1 \%$ Logement" were not the main actors interested in the reservation of intermediate social housing. Only in Val-de-Marne one fifth of intermediate flats were reserved by this entity. Actually, more than one third of these flats remained unreserved in three suburban departments and $14.4 \%$ in Paris. In Seine-Saint-Denis this number exceeds 50\% which means that reserving entities were less interested in supporting this segment of social housing in this department. As a result, the construction of intermediate social housing could be assumed as a proxy to diversify the landlords' housing stock and attract tenants representing middle-income categories.

Finally, the third hypothesis was not accepted as the phenomenon of reduced rents occurred in communes no matter what share

${ }^{6}$ Dwellings for sale offered to the households who fulfill specific requirements (e.g. income levels). of social housing they had. Furthermore, more significantly in the case of the Paris metropolitan area was the number of intermediate social housing with increased rents which showed that in spite of many criticisms of this segment, it may become an attractive option for the households especially in the communes where the prices in the real estate market are higher.

If we broaden the reflection for the whole île-de-France region, a high concentration of newly constructed intermediate social housing dominates in Paris. This could be explained by the presence of eligible requests or opportunities resulting from specific local policies or regional aid granted to particular communes having between 20 and 40\% of social housing (Brimbal 2011). Moreover, intermediate social housing is present in the communes in Essonne and Yvelines departments (less in Val-d'Oise), mainly in the immediate vicinity of Hauts-de-Seine, Val-de-Marne and Seine-Saint-Denis (Joinet 2011a). It is also worth noting that their share within social housing stock is higher in those communes of the outer suburbs than in Val-de-Marne located the same distance from Paris (Joinet 2011a). Furthermore, although intermediate social housing is concentrated in Paris and the inner suburbs, it was estimated that this segment would be very competitive with home ownership if the dwellings were built in certain areas in Yvelines department (Brimbal 2011). Hence, the importance of intermediate social housing is not restricted to the boundaries of the Grand Paris metropolitan area.

In 2014, the new regulation concerning intermediate housing ${ }^{7}$ has reinforced its importance in the areas of continued urbanization with over 50,000 inhabitants, as well as in the municipalities of over 15,000 inhabitants, with a high population growth. Indeed, PLS and PLI dwellings and the roles attributed to this housing segment may evolve and nuance the differences between the municipalities where the share of social rental housing is similar.

\footnotetext{
2014.

7 Regulation no. 2014-159 from the 20th February
} 


\section{Acknowledgments}

This work was supported by the Polish Ministry of Science and Higher Education under Grant entitled: Zaplanowane różnicowanie składu społecznego wobec segregacji społecznoprzestrzennej. Polityka mixité sociale na obszarze metropolitalnym Paryża [Planned diversification of social composition in the face

\section{References}

AbraCl S., RAE I., 2013. Mixed-Tenure Neighbourhoods in London: Policy Myth or Effective Device to Alleviate Deprivation? International Journal of Urban and Regional Research, vol. 37, no. 2, pp. 451-79.

Atlas des Franciliens, 2013. Paris: Institut d'aménagement et d'urbanisme Île-de-France (IAUîdf), La Documentation française.

Bacqué M.-H., Fijalkow Y., Flamand A., VerMEERSCH S., 2010. Comment Nous Sommes Devenus HLM, Les Opérations de Mixité Sociale à Paris dans les Années 2000. Espaces et Sociétés, vol. 140-141, nos. 1-2, pp. 93-111.

Bacqué M.-H., FiJalkow Y., 2012. Social Mix as the Aim of a Controlled Gentrification Process: the Example of the Goutte d'Or District in Paris [in:] G. Bridge, T. Butler, L. Lees (eds.), Mixed communities. Gentrification by stealth?, Bristol: Policy Press, pp. 115-132.

Berger M., 2004. Les périurbains de Paris. De la ville dense à la métropole éclatée? Paris: CNRS Éditions.

Berger M., Saint-Gérand T., 1993. La division sociale de l'espace périurbain en Île-de-France. Strates [on line], 7, http://strates.revues.org/1124 [10 September 2010].

Bergsten Z., Holmqvist E., 2013. Possibilities of building a mixed city - evidence from Swedish cities. International Journal of Housing Policy, vol. 13, no. 3, pp. 288-311.

Boschman S., Bolt G., van Kempen R., van Dam F., 2013. Mixed neighbourhoods: Effects of urban restructuring and new housing development. Tijdschrift voor Economische en Sociale Geografie, vol. 104, no. 2, pp. 233-242. of social segregation. The policy of social mix in the metropolitan area of Paris], [no. 918/ MOB/2012/0].

Editors' note:

Unless otherwise stated, the sources of tables and figures are the authors', on the basis of their own research.

Bourgeols C., 2004. L'attribution des logements sociaux. Politique publique et jeux des acteurs locaux. Paris: L’Harmattan.

Bretherton J., Pleace N., 2010. A Difficult Mix: Issues in Achieving Socioeconomic Diversity in Deprived UK Neighbourhoods. Urban Studies, vol. 48, no. 16, pp. 3433-3447.

Brimbal C., 2011. L'étude 'PLS en Île-de-France'. Groupe bailleurs de l'Observatoire du logement social. Paris: Institut d'aménagement et d'urbanisme Île-de-France, pp. 19-21.

Davidson M., LeEs L., 2005. New-build 'gentrification' and London's riverside renaissance. Environment and Planning A, vol. 37, pp. 1165-1190.

Françols J.-Ch., Ribardière A., Fleury A., Mathian H., Pavard A. \& Saint-Julien, T., 2011. Les Disparités de Revenus des Ménages Franciliens, Analyse de l'évolution 1990-1999-2007, Paris: DRIEA IF/SCEP.

GENEST S., 2005. Logement et mixité: une obligation de moyens en constante évolution. Les cahiers Profession Banlieue. Mixité sociale, un concept opératoire?, mars 2005, pp. 41-57.

Graham E., Manley D., Hiscock R., Boyle P., DOHERTY J., 2009. Mixing Housing Tenures: Is it Good for Social Well-being?. Urban Studies, vol. 46, no. 1, pp. 139-165.

Guillouet J.J., 2011. Une approche des ménages à revenus moyens d'après les plafonds PLS et PLI. Exploitation de l'enquête logement 2006 de l'Insee. Les logements sociaux intermédiaires, Groupe bailleurs de l'Observatoire du logement social, Rapport d'activité 2010, Paris: IAU île de France, http://www.iau-idf.fr/savoir-faire/nostravaux/edition/les-logements-sociaux-intermediaires.html [15 May 2015]. 
Horenfeld G., 1998. L'univers des HLM [in:] M. Segaud, C. Bonvalet, J. Brun (eds.), Logement et habitat, l'état des savoirs, Paris: Éditions La Découverte, pp. 136-146.

HouArd N., 2009. Droit au Logement et Mixité. Les Contradictions du Logement Social. Paris: l'Harmattan.

Hort H., 1939. The structure and growth of residential neighborhoods in American cities. Federal Washington D.C.: Housing Administration.

IAU, 2011. La demande de logements locatifs sociaux en Île-de-France en 2010. Paris: I'Institut d'Aménagement et de I'Urbanisme d'île-deFrance, http://www.iau-idf.fr/savoir-faire/nos-travaux/edition/la-demande-de-logements-locatifssociaux-en-ile-de-france-en-2010.html [15 May 2015].

JACQUESSON F., 2006. Les zones urbaines sensibles franciliennes: des réalités diverses. Île-de-France à la Page, no. 271, Paris: INSEE, http://www. insee.fr/fr/insee_regions/idf/themes/alapage/ alap_2000_2006/alapage271.pdf [15 May 2015].

JOINET H., 2011a. Le logement social intermédiaire en Île-de-France. Note rapide 547, mai 2011, Paris: Institut d'aménagement et d'urbanisme Île-de-France, http://www.iau-idf.fr/savoir-faire/ nos-travaux/edition/le-logement-social-intermediaire-en-ile-de-france.html [15 May 2015].

JOINET H., 2011b. Le logement social intermédiaire en Île-de-France. Groupe bailleurs de l'Observatoire du logement social. Paris: Institut d'aménagement et d'urbanisme Île-de-France, http:// www.iau-idf.fr/savoir-faire/nos-travaux/edition/ les-logements-sociaux-intermediaires.html [15 May 2015].

Kearns A., Mason P., 2007. Mixed Tenure Communities and Neighbourhood Quality. Housing Studies, vol. 22, no. 5, pp. 661-691.

KLEINHANS R., 2004. Social implications of housing diversification in urban renewal: A review of recent literature. Journal of Housing and the Built Environment, vol. 19, no. 4, pp. 367-390.

Lainé-Daniel F., Noyé Ch., Rathier F., 2013. Politiques de Peuplement et Logement Social. Premiers Effets de la Rénovation Urbaine. Étude du Comité d'Évaluation et de suivi de l'ANRU, Paris: La Documentation Française.

Lefebvre H., 1968. Le Droit à la ville. Paris: Anthropos.
Lelévrier Ch., 2006. Politique de la ville: gestion des territoires et mobilités [in:] D. Fraboulet, D. Rivière (eds.), La ville sans bornes, la ville et ses bornes, Paris: Éditions Nolin, pp. 265-279.

LelÉVRIER Ch., 2008a. Mobilités et Trajectoires Résidentielles des Ménages Relogés lors d'Opérations de Renouvellement Urbain. Synthèse de Travaux Menés entre 2004 et 2007. Paris: PUCA.

LelÉVRIER Ch., 2008b. Pratiques de Logeurs: de la Mixité aux Processus de Regroupements [in:] M.-Ch. Jaillet, E. Perrin, F. Ménard (eds.), Diversité sociale, ségrégation urbaine, mixité, no. 180, Paris: PUCA, pp. 233-247.

LelÉVRIer Ch., 2010. La Mixité dans la Rénovation Urbaine: Dispersion ou Re-concentration? Espaces et sociétés, nos. 140-141 (1), pp. 59-74.

Lelévrier Ch., Gestin A., Le Garrec S., Noyé Ch., VIgnal C., 2007. Mobilités et Trajectoires Résidentielles des Ménages dans Trois Opérations de Rénovation Urbaine en Île-de-France, no. 899, Paris: PUCA.

Livingston M., Kearns A., Balley N., 2013. Delivering Mixed Communities: The Relationship between Housing Tenure Mix and Social Mix in England's Neighbourhoods. Housing Studies, vol. 28, no. 7, pp. 1056-1080.

LUPTON R., TUNSTALL R., 2008. Nieghbourhood regeneration through mixed communties: A 'social justice dilemma'? Journal of Education Policy, vol. 23, no. 2, pp. 105-117.

Murie A., Musterd S., 1996. Social segregation: Housing tenure and social change in Dutch Cities in the Late 1980s. Urban Studies, vol. 33, no. 3, pp. 495-516.

Musterd S., Andersson R., 2005. Housing mix, social mix, and social opportunities. Urban Affairs Review, vol. 40, no. 6, pp. 761-790.

OLAP, 2012. Les loyers des logements privés (agglomération parisienne et province), Chiffres clés 2012. http://www.observatoire-des-loyers. $\mathrm{fr} /$ sites/default/files/olap_documents/publications_periodiques/4\%20pages-2012.pdf [8 November 2015].

PInçon M., 1976. Les H.L.M.: Structure sociale de la population logée: Agglomération de Paris 1968. Paris: CSU.

Pinçon M., Pinçon-Charlot M., 2004. Sociologie de Paris. Paris: La Découverte. 
PréteCeille E., 2003. La division sociale de l'espace francilien. Typologie socioprofessionnelle 1999 et transformations de l'espace résidentiel 1990-1999. Paris: Observatoire Sociologique du Changement FNSP-CNRS.

PréteCeille E., 2006. La ségrégation sociale a-t-elle augmenté? La métropole parisienne entre polarisation et mixité. Sociétés Contemporaines, 62, pp. 69-93.

PréteCeille E., 2012. Segregation, Social Mix and Public Policies in Paris [in:] T. Maloutas \& K. Fujita (eds.), Residential Segregation Around the World: Making Sense of Contextual Diversity, Furnham: Ashgate, pp. 153-176.

RAAD L., 2014. Transformations sociales en banlieue rouge. Politiques locales, stratégies résidentielles et inscription territoriale des classes moyennes. Paris: Université Paris Diderot Paris 7, [PhD dissertation].
RAPPORT SUR LES MODES ET MÉTHODES D'ATTRIBUTION DES lOgementS SOCIAUX À PARIS: ÉtAT DES LIEUX et mise en Perspective, 2012. Paris: Marie de Paris, https://api-site.paris.fr/images/71726 [8 November 2015].

Rhein C., Berger M., 1988. Parc de logements, structure des ménages et division sociale de l'espace en région île-de-France. Strates, 3, pp. 85-130.

SAGOT M., 2013. Géographie sociale et habitat en Ile-de-France, Evolutions 2001-2011, Paris: IAU îdf.

Stébé J.-M., 2009. Le logement social en France. Paris: PUF.

Whitehead C., SCAnlon K. (eds.), 2007. Social Housing in Europe. London: LSE.

Winters S., Elsinga M., 2008. The Future of Flemish social housing. Journal of Housing and the Built Environment, vol. 23, no. 3, pp. 215-230. 


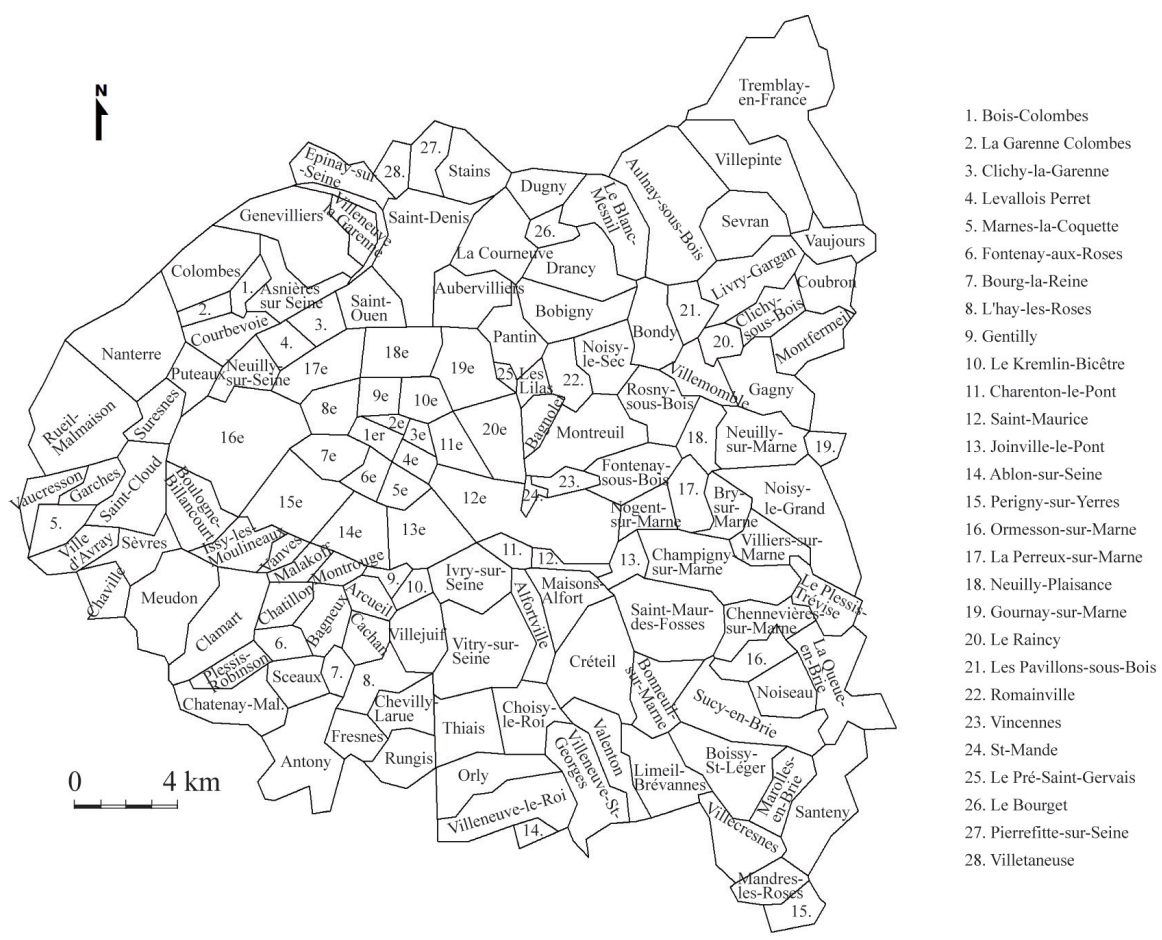

Annex 1. Paris and first ring of suburbs: administrative division into communes 